\title{
Konsep Kepemimpinan Catur Kotamaning Nrepati Dalam Kakawin Niti Sastra
}

\author{
Oleh
}

\author{
I Putu Agus Aryanaya Giri
}

\begin{abstract}
Actually, the societies want a figure of leader that has credibility, social life, and can protect and guide the societies well. However the reality is, nowadays there are many leaders who are not trusted by the societies because of their negative behavior. Talking about this phenomenon, actually Hinduism has produced various kinds of doctrines about the philosophy of life especially about leadership since many years ago. Unfortunately that doctrine has not been known and applied in maximum way. Kakawin Niti Sastra is one of classical Hindu literature that has full values of leadership and it shall be used as source of research. The structures of leadership in Kakawin Niti Sastra consists of Prabhu, Purohita, Amatya, Nāradhipati, Sena and Sanggya. Catur Kotamaning Nrepati leadership Concept in Kakawin Niti sastra consists of the value of wisdom (jnana wisesa suddha), compassion (kaprahitaning praja), bravery (kawiryan), and authority (wibhawa).
\end{abstract}

Keywords : Catur Kotamaning Nrepati Leadership, Kakawin Niti Sastra

\section{PENDAHULUAN}

Tatanan kehidupan sosial pada hakikatnya tidak bisa terlepas dari sistem kepemimpinan, baik sebagai pemimpin maupun sebagai pengikut yang dipimpin. Berbagai organisasi seperti lembaga pendidikan, lembaga keagamaan, organisasi sosial kemasyarakatan, organisasi sosial kekuatan politik dan sebagainya bahwa masalah kepemimpinan selalu muncul ke permukaan, apalagi dalam kehidupan kenegaraan. Kalau disimak berita-berita di media massa, secara langsung ataupun tidak langsung, bahwa kepemimpinan selalu mendapat tempat istimewa dan sering menjadi isu sentral.

Thoha (2012:1) juga mengungkapkan hal yang senada, bahwasanya membicarakan masalah kepemimpinan adalah hal yang sangat menarik dan dapat dimulai dari sudut mana saja akan diteropong. Dari waktu ke waktu kepemimpinan menjadi perhatian manusia. Ada yang yang berpendapat masalah kepemimpinan itu sama tuanya dengan sejarah manusia. Kepemimpinan dibutuhkan manusia, karena adanya suatu keterbatasan dan kelebihan-kelebihan tertentu pada manusia. disatu pihak manusia memiliki kemampuan terbatas untuk memimpin, dipihak lain ada orang yang mempunyai kelebihan kemampuan untuk memimpin. Disinilah timbulnya kebutuhan akan pemimpin dan kepemimpinan.

Sejatinya, masyarakat menginginkan figur seorang pemimpin yang memiliki kredibilitas, jiwa sosial, serta mampu mengayomi dan membimbing masyarakatnya. Sebab, realita yang terjadi banyak para pemimpin jaman sekarang nampaknya mengalami krisis kepercayaan dari masyarakat. Banyak pemimpin di Indonesia mulai dari sekup terkecil sampai yang terbesar terjerat masalah hukum karena melakukan korupsi. Masyarakat sepertinya antipati akan janji-janji yang diberikan pemimpin ketika berkampanye, karena kenyataannya ketika sudah menjabat para pemimpin tersebut cenderung memperkaya dirinya sendiri tanpa memikirkan keadaan rakyatnya yang menderita. 
Melihat berbagai fenomena tersebut, sebenarnya ajaran agama Hindu sejak dahulu telah melahirkan berbagai macam ajaran mengenai falsafah kehidupan utamanya tentang kepemimpinan. Hanya saja ajaran tersebut belum di ketahui dan diamalkan secara maksimal. Namun, pada perkembangan dewasa ini, banyak dijumpai naskah-naskah kesusastraan yang memberikan tuntunan dan petunjuk bagi umat manusia tentang kebenaran dan kebijaksanaan yang mesti dijalankan dalam kehidupan di dunia ini. Semua naskah kesusastraan tersebut nampaknya merupakan bentuk evolusi dan penjabaran dari nilai-nilai yang substansinya ada dalam kitab suci Weda.

Subagiasta (2010:1) mengungkapkan bahwasanya menanamkan ajaran kepemimpinan Hindu sesuai sumber suci ajaran agama Hindu kepada para generasi muda (sekaa teruna teruni) atau kelompok pemuda-pemudi, para pemimpin dalam bidang pendidikan, maupun komponen kependidikan yang lainnya adalah hal yang positif dan terpuji guna meningkatkan pemahaman dan praktek kepemimpinan Hindu sesuai dengan kapasitasnya masing-masing. Generasi muda Hindu merupakan kader penerus bangsa. Oleh sebab itu, perlu adanya kesadaran dari berbagai pihak guna mewujudkan kader-kader penerus bangsa yang memiliki mental kuat dan pengetahuan spiritual yang baik.

Kakawin Niti Sastra merupakan salah satu karya sastra klasik yang sarat dengan nilainilai kepemimpinan dan wajib dijadikan sumber penelitian. Kakawin Niti Sastra sebagai salah satu produk sastra Hindu klasik, banyak mengandung ajaran-ajaran tentang kepemimpinan, sehingga perlu dikembangkan dan disebarluaskan di kalangan masyarakat, sebagai pedoman dalam mewujudkan kehidupan yang harmonis. Kakawin Niti Sastra mungkin dipersepsikan masyarakat secara umum hanya sebatas kutipan syair-syair yang sangat menarik untuk di tembangkan dalam acara pesantian, sehingga perlu diadakan pengkajian untuk mengetahui nilai-nilai yang terdapat didalamnya.

\section{Tinjauan Historis Kakawin Niti Sastra}

Sebuah telaah yang kritis dan komparatif terhadap sastra kakawin dapat membantu untuk mencapai beberapa kesimpulan umum mengenai kronologinya. Tetapi menentukan tanggal ditulisnya sebuah karya tertentu hendaklah dilakukan dengan menyediakan kelonggaran yang tidak hanya meliputi puluhan tahun tetapi bahkan berabad-abad. Selain itu kita tak dapat mengesampingkan kemungkinan bahwa dalam beberapa periode tertentu atau di beberapa pusat kegiatan leterer bahasa Kawi dipelajari dengan lebih intensif, sehingga puisi yang dihasilkan periode itu atau di pusat itu memperlihatkan kesamaan yang besar dengan periode klasik dari pada karya-karya yang ditulis pada jaman Renaissance dengan gaya ala Cicero, ditulis jauh lebih dahulu daripada sebuah karya prosa yang ditulis jauh lebih dahulu daripada sebuah karya sejenis dari periode latin Abad pertengahan. Dengan demikian dapat disimpulkan, bahwa kurun waktu yang menghasilkan sastra kakawin hampir seribu tahun lamanya. Semua itu termasuk sastra Jawa Kuno. Biarpun mengenai beberapa kakawin dapat dipastikan bahwa itu ditulis di Bali, namun pantas dicatat, bahwa hanya jarang sekali kita berjumpa dengan suatu ungkapan khas Bali (Zoetmulder, 1985: 32).

Mengenai tinjauan historis kakawin Niti Sastra, sebenarnya penulis merasa masih terbatas dalam hal menemukan literatur tertulis mengenai kapan tepatnya kakawin tersebut disusun. Namun, jika kita telaah dari buku Kalanguan karya P.J Zoetmulder, ada sebuah titik terang yang mengungkapkan bahwa kakawin Niti Sastra itu kemungkinan ditulis pada abad ke-19. Wiana dalam modul Nitisastra (1996: 28) menjelaskan bahwa :

Naskah Jawa Kuno yang sepenuhnya merupakan naskah Niti Sastra adalah naskah dalam bentuk Kakawin yang bernama Kakawin Niti Sastra. Isi naskah ini sangat mirip dengan Canakya Nitisastra. Apakah Kakawin Niti Sastra ini bersumber dari Canakya Nitisastra Sansekerta, hal ini membutuhkan penelitian ilmiah lebih lanjut. Banyak yang menduga Kakawin Niti 
Sastra ditulis oleh Dang Hyang Dwijendra, sejauh mana kebenaran tersebut masih perlu diteliti lebih lanjut.

Khusus tentang teks Kakawin Niti Sastra yang di gunakan dalam tulisan ini awalnya merupakan hasil terbitan tahun 1955 oleh R. Ng. Dr. Poerbatjaraka dengan salinannya dalam bahasa Belanda (Bebliotheca Javanica 54 No. B 1483) dan naskah Niti Sastra dalam bahasa Indonesia yang diterbitkan oleh Balai Prestaka (BP No. 1630). Baru kemudian pada tahun 1987 disusun kembali kedalam dua bahasa yaitu bahasa Jawa Kuno (kawi) dan Indonesia oleh tim PGAHN (Persatuan Guru Agama Hindu Negeri) 6 Singaraja.

\section{Struktur Kepemimpinan Dalam Kakawin Niti Sastra}

Struktur kepemimpinan merupakan sebuah struktur yang disusun sebagai pola kerja untuk melakukan tugas-tugas organisasi hanya berhubungan dengan pemecahan masalahmasalah yang terkait dengan lingkungan internal maupun eksternal (Badeni, 2013: 210). Struktur kepemimpinan dalam Kakawin Niti Sastra tidak dijelaskan secara jelas dan mendetail, hanya diselipkan dalam sebagian kecil kutipan-kutipan kakawinnya.

Istilah pemimpin tertinggi dalam Kakawin Niti sastra disebut dengan istilah Prabhu. Kata "Prabhu" berasal dari bahasa Sansekerta yakni kata "Pra" yang artinya di depan dan "bhu" artinya ada. Kata Prabhu artinya yang berada di depan (Wiana, 1996: 183). Prabhu dalam bahasa Jawa Kuno artinya Raja (Zoetmulder, 1996: 834). Hal ini dapat dilihat dari Kutipan Kakawin Niti Sastra XV. 3 :

Tingkahnikang prabhu sumīksa ri bhretya sanggya

Sakwehnya kottama kamadhya lawan kanista

Yeka warah-warahaneka ya karma yukti

Sangkeng kutāra gêlarên têkaping sumiksa

Terjemahan :

Jika raja akan memberi pelajaran kepada segenap rakyatnya, yang utama, yang madya (tengah) dan yang nista, ia harus mendidik mereka berkelakuan baik dengan jalan membentangkan"kutara" dalam hal inilah ia harus mengajar rakyatnya (Tim, 1987: 57).

Prabhu dalam pengertian yang lebih luas artinya yang berkuasa. Menilik arti katanya, tentunya Prabhu tersebut berarti penguasa yang paling terkenal, terkemuka, dan paling menentukan. Kata Prabhu ini mungkin identik artinya secara etimologi dengan istilah "Presiden". Kata Presiden dalam bahasa Latin yang juga artinya "yang berada di depan" (Wiana, 1996: 183-184). Pemimpin pada dasarnya digolongkan ke dalam Ksatriya Varna yang ditegaskan fungsinya dalam Manawadharmasastra I. 89 :

\section{Prajanam raksanam danam, ijyadhyayanamewa ca, wisayeswaprasaktaticca ksatriyasya samasatah.}

Terjemahan ;

Kewajiban-kewajiban seperti melindungi rakyat, memberi dana, menyelenggarakan upacara yadnya, mempelajari Weda dan menguasai diri dari keterikatan atas benda-benda jasmani dinyatakan Ksatriyalah itu (Pudja, Sudharta, 2002: 50).

Sloka tersebut menegaskan bahwa Tuhan telah menetukan tugas seorang pemimpin untuk melindungi rakyat dari ancaman rasa tidak aman dan memberikan hadiah-hadiah berupa harta benda, mempelajari Veda dan mengekang nafsu. Jadi, sebelum seseorang mampu mengendalikan dirinya sendiri maka seseungguhnya belum bisa dikatakan sebagai seorang pemimpin yang sejati. Untuk mewujudkan kemakmuran dalam masyarakatnya, seorang pemimpin tidak cukup mengatasi kemiskinan masyarakatnya secara material saja, namun juga harus bisa mengatasi kemiskinan secara rohani (nonfisik) yang salah satunya adalah berupa kebodohan dengan jalan mendidik masyarakatnya secara intelektual maupun moral melalui dialog langsung ataupun melalui kebijakan yang terkait dengan penyelenggaraan pendidikan di wilayahnya. 
Pemimpin pada dasarnya juga merupakan manusia biasa yang memiliki keterbatasan dan seringkali sulit untuk memutuskan suatu kebijakan tanpa adanya pertimbangan dari figur yang benarbenar bijaksana dan paham akan ajaran agama. Maka dari itu, diperlukanlah sosok pendeta istana (Purohita) selaku penasehat raja. Hal ini dijelaskan dalam kutipan Kakawin Niti Sastra XV. 1 :

\section{Lwirning purohita wiśesa ri sang narendra sang wruh ri śāstra putusinng paramādhi kawi \\ ring widya sāra sarasāhuwusan kagêgwan sakteng śiwārcana sadāgama tan kaluptan}

Terjemahan :

Pendeta istana yang utama harus memenuhi syarat-syarat ini: ia harus tahu akan buku-buku ajaran, faham benar akan syair-syair yang indah lagi penting isinya, mengenal betul akan inti dan arti ilmu pengetahuan. Ia harus menyembah Siwa dan menjalankan agama dengan patuh (Tim, 1987: 57).

Purohita atau pendeta istana yang utama mempunyai kedudukan yang sangat berpengaruh di dalam sistem politik Hindu dan merupakan penasehat raja di bidang keagamaan dan kebijaksanaan mengenai kerohanian. Pendeta istana harus paham betul tentang ajaran agama, baik yang menyangkut teori maupun praktek. Pendeta istana harus bisa menjadi tauladan bagi segenap masyarakatnya, terutama harus taat menjalankan ajaran agama serta rajin menyembah Tuhan sebagai wujud bhakti. Seorang raja dinobatkan oleh seorang Purohita disebut Rajasuya, sebaliknya Purohita dilantik oleh raja dinamai Brhaspatisawa. Sejak zaman dahulu Purohita dan Raja bekerja sama sebagai dwi tunggal. Dalam sebuah negara, Purohita memelihara keagamaan dengan menyelenggarakan upacara seremonial atau keagamaan untuk negara. Kadangkala juga mengikuti raga ke medan perang serta seringkali melakukan operasi di dalam medan perang. Seorang Purohita mempunyai kekuatan gaib dan dapat menghubungkan diri dengan Tuhan untuk memohon keselamatan raja dan negara. Purohita juga memimpin upacara untuk raja karena itu adalah kewajiban spiritual dan keadaan yang memberikan pengaruh kepada raja di dalam berbagai hal yang penting baik bersifat umum maupun bersifat politik (Wiana, 1996: 92-93).

Selain itu, seorang raja dalam menjalankan kebijaknnya untuk mensejahterakan masyarakat di segala bidang sudah tentu memerlukan pembantu yang tentunya berasal figur-figur terbaik dan benar-benar ahli di berbagai bidang. Figur tersebut disebut dengan istilah amatya. Dalam bahasa Jawa Kuno, amatya diartikan sebagai pengiring raja, menteri, atau pejabat tinggi (Zoetmulder, 1997: 28). Amatya ini dijelaskan dalam kutipan Kakawin Niti Sastra XV. 10:

Yan sājna sang prabhu pakaryanirang amatya tri pwekanang phala kabhukty anuteng swa-raja swargādi len ikang dhanagama tang kapangguh sangkeng kaçaktining amatya maweh kasiddhanan.

Terjemahan :

Jika menteri kerajaan selalu menurut perintah raja, maka dia akan mendapat pahala tiga macam. Dengan mengikuti raja ia pertama-tama akn mencapai surga; lain dari itu kekayaan dan kenikmatan agama. Dalam kecakapan menteri itu terletak kesempurnaan hasil pekerjaan (raja) (Tim, 1987: 59).

Seorang raja adalah kurang bijak jika menjalankan administrasi pemerintahan sendiri. Raja harus menghubungi menteri-menteri yang mendampinginya dalam memecahkan masalah-masalah yang umum maupun masalah yang bersifat khusus. Sebaliknya, masalahmasalah yang kecil timbul sebagai sebuah kesibukan tanpa menteri, raja tidak akan dapat memecahkan kesulitan tersebut dengan baik. Kautilya mengatakan bahwa seorang raja akan bisa berhasil apabila mendapatkan bantuan dari pelaksana-pelaksana tersebut (para menteri). Hal itu diumpamakan sebagai sebuah roda, tidak akan dapat menjalankan kereta dengan baik. Kekuatan atau jumlah kementerian itu tergantung dari ukuran pemerintah itu sendiri, kepentingan atau masalah-masalah yang dihadapi oleh sebuah negara (Wiana, 1996: 91). 
Sebuah negara tentunya tidak bisa terlepas dari ancaman (treath) atau masalah keamanan. Ancaman tersebut bisa datang dari dalam maupun dari luar. Maka dari itu perlu adanya sistem pengamanan dan pertahanan yang kuat dalam sebuah pemerintahan. Seorang raja harus memiliki pasukan perang yang dikomandoi oleh pemimpin pasukan yang berjiwa berani, tidak pandang bulu, dan memiliki hasrat membunuh demi kedaulatan negara. Sebagaimana yang diungkapkan dalam kutipan Kakawin Niti Sastra XV. 8:

Lwirning narādhipatining bala ring swasena Pāt kwhnya rakwa huningan pwa rêngonta mangke Bwat krūna sāhasa, krêpāna sudhira malwat Len warnasangkara kunang mamati tapaswi

Terjemahan :

Pemimpin tentara hendaknya mempunyai empat sifat ini; ganas (bertindak dengan keganasan), kikir, tidak mengindahkan adanya kasta-kasta dan mempunyai hasrat membunuh orang yang bertapa (Tim, 1987: 59).

Narādhipati berasal dari bahasa Jawa Kuno yang berarti pemimpin (termasuk pasukan/tentara) (Zoetmulder, 1996: 691). Pemimpin pasukan yang hebat sudah tentu harus didukung oleh pasukan tentara yang hebat pula. Tentara dalam bahasa Jawa Kuno disebut dengan istilah sena (Zoetmulder, 1996: 1078). Konotasi membunuh bagi seorang pemimpin tentara maupun pasukannya bukan berarti bertindak semena-mena menghilangkan nyawa orang lain. Pemimpin maupun masyarakat di wilayahnya tentunya menginginkan rasa aman dan nyaman dalam menjalankan aktivitas. Maka dari itu, perlu adanya sifat keganasan dan berani untuk membasmi musuh yang dianggap membahayakan, meskipun musuh tersebut berasal dari golongan terhormat dan suci sekalipun. Akan terlihat lucu apabila ada pemimpin perang yang memiliki sifat melankolis dan belas kasihan ketika berhadapan dengan musuh. Hal tersebut bisa jadi akan membinasakan dirinya sendiri.

Setelah itu, faktor yang tidak kalah penting adalah adanya rakyat / masyarakat yang menjadi pendukung seorang pemimpin dan jajarannya dalam menjalankan sebuah pemerintahan. Dalam bahasa Jawa Kuno, masyarakat / rakyat disebut dengan istilah sanggya (Zoetmulder, 1996: 1020). Tanpa adanya rakyat, maka seorang raja tidak akan ada yang mengakui, menghormati dan menjunjung. Rakyat bukan berarti individu yang siap diperbudak, melainkan juga sebagai pelaksana lapangan setiap kebijakan yang dikeluarkan oleh pemimpin. Misalnya saja kebijakan pemimpin dalam pelaksanaan upacara yadnya, maka sudah pasti secara teknis lapangan mulai dari persiapan bahan sampai dengan pelaksanaan akan dititikberatkan pada masyarakat meskipun secara konsep dirancang oleh pemimpin. Selain itu, rakyat juga sebagai figur penilai apakah program atau kebijakan pemimpin sudah berjalan dengan baik atau tidak. Hal itu kemudian yang akan menjadi sebuah indikator apakah kepemimpinan seseorang berhasil atau tidak.

Bercermin dari penjelasan tersebut, dapat disimpulkan bahwa keberhasilan seorang pemimpin (prabhu) dalam menjalankan sebuah pemerintahan tidak bisa terlepas dari dukungan subsistem organisasi yang ada dibawahnya baik itu Purohita (pendeta istana), Amatya (menteri), Nāradhipati (pemimpin tentara), Sena (tentara) dan Sanggya (rakyat/masyarakat). Hubungan tersebut dapat berjalan dengan baik, apabila terjalin suatu komunikasi yang komunikatif antara pimpinan (Prabhu) dengan bawahannya. Bila salah satu saja struktur organisasi tersebut bermasalah, maka sudah tentu akan mempengaruhi struktur yang lainnya.

\section{Konsep Kepemimpinan Catur Kotamaning Nrepati Dalam Kakawin Niti Sastra}

Kepemimpinan adalah seni menggerakkan orang lain guna mencapai tujuan tertentu atau tujuan bersama. Kepemimpinan sebagai seni (art) untuk menciptakan kepatuhan orang lain pada pemimpin. Kepatuhan orang lain yang dimaksud adalah kepatuhan bawahan/staf atau anggota suatu kelompok tentu atas pengaruh, arahan atau panutan yang diberikan oleh pemimpin itu sendiri (Suyana, 2011: 76). 
Kitab Sapta Parwa menyebutkan bahwa ada empat sifat utama yang harus dimiliki oleh seorang Raja atau pemimpin yang disebut dengan Catur Kotamaning Nrepati (Wiana, 1996: 200). Pembagian Catur Kotamaning Nrepati adalah :

1. Jnana Wisesa Sudha artinya berpengetahuan luhur dan suci (bijaksana)

2. Kaprahitaning Praja artinya welas asih kepada rakyat

3. Kawiryan artinya pemberani dan pantang menyerah dalam membela kebenaran

4. Wibawa artinya kewibawaan.

Melalui telaahmendalam secara hermeneutik (penafsiran) konsep kepemimpinan Hindu yang diuraikan dalam Kakawin Niti Sastra ternyata sama substansinya dengan Kitab Sapta Parwa antara lain Jnana Wisesa Suddha (Kebijaksanaan), Kaprahitaning Praja (Welas Asih), Kawiryan (Keberanian), dan Wibhawa (Kewibawaan).

\subsection{Jnana Wisesa Sudha (Kebijaksanaan)}

Kebijaksanaan menurut Kamus Lengkap Bahasa Indonesia, adalah sikap adil dan selalu menggunakan akal dalam setiap langkah perbuatannya (Nurhayati: 2012: 139). Wiana (1996: 200) menjelaskan bahwa kebijaksanaan (Jnana Wisesa Suddha) merupakan keharusan bagi seorang raja (pemimpin) untuk mempunyai ilmu pengetahuan yang suci. Ilmu pengetahuan suci tentunya diperoleh dari kitab suci agama. Dalam hal ini, Orang yang bijaksana merupakan orang yang memiliki "kecerdasaan intelektual dan moral" yang diperoleh dari mempelajari kitab suci Weda (Jnana Wisesa Suddha). Dalam astribut Dewi Saraswati, sikap bijaksana tersebut disimbolkan dengan angsa sebagai unggas yang dianggap istimewa karena cara makannya mampu memisahkan antara kotoran dan apa yang dimakannya, demikian angsa mampu mebedakan baik dan buruk serta benar dan salah (Atmadja, 2014: 44).

Menelaah nilai kebijaksanaan seorang pemimpin dalam Kakawin Niti Sastra tidak bisa terlepas dari hakikat manusia sebagai makhluk
Tuhan yang paling sempurna. Hal tersebut di dasari oleh sebuah asumsi yang menyatakan bahwa makhluk yang hidup di dunia ini dibagi atas tiga golongan besar, yaitu tumbuh-tumbuhan, binatang dan manusia. Dalam ajaran agama Hindu, dikatakan bahwa tumbuh-tumbuhan itu hanya memiliki bayu yaitu kemampuan bergerak saja, binatang hanya memiliki bayu dan sabda yaitu kemampuan bergerak dan bersuara saja. Berbeda halnya dengan manusia, di samping memiliki bayu dan sabda ( kemampuan bergerak dan berbicara) juga memiliki idep yaitu kemampuan berpikir. Idep inilah kelebihan manusia dari makhluk-makhluk lain (Awanita, dkk, 1995: 38). Senada dengan hal tersebut, Koentjaraningrat (2009: 78) juga menyatakan bahwa otak manusia dapat dikatakan berevolusi paling jauh jika dibandingkan dengan makhluk lainnya.

Untuk menjaga pikiran agar arahnya tidak bertentangan dengan tujuan ataupun cita-cita hidup manusia perlu dikendalikan. Pikiran yang tidak terkendali, ibaratnya kuda-kuda liar yang arahnya tidak menentu, tidak tahu jalan ke mana harus pergi. Janganlah sekali menuruti pikiran sembarang orang, agar kita tidak terjerumus ke dalam jurang penderitaan. Sebagaimana yang diungkapkan dalam Kakawin Niti Sastra IV.18 :

Ring wwang haywa manūt I buddhinikanang prajana matemah wināsa ya. Yan stri buddhi tinūtaken pati temahnya hinirang-iranging parampara. Yapwan sātmaka buddhi tusta temahanya mangangen-angeneka pürwaka. Byaktā manggihaken wisesa kita yan lumekasakena buddhining guru.

Terjemahan :

Jangan sekali-kali menurut pikiran sembarang orang, agar jangan binasa. Jika kita menurut pikiran wanita, kita akan menemui ajal kita dan akan diperolok-olok orang buat selamalamanya. Jika kita menggunakan pikiran sendiri sebelum berbuat apa-apa akan merasa senang. Adapun yang tentu akan baik akibatnya ialah jika kita menurut pikiran guru (Tim, 1987: 3334).

Kutipan bait kakawin tersebut menyiratkan makna yang mendalam bahwasanya sebagai 
manusia haruslah menjadi insan yang cerdas dalam menerima sebuah pemikiran yang datang dari luar diri. Artinya, pintar-pintarlah memilah pendapat sebelun direalisasikan dalam sebuah tindakan. Hal yang penting juga untuk di bahas berkenaan dengan bait kakawin tersebut, bahwasanya seseorang harus mengikuti apa yang dikatakan oleh guru sebagai sebuah pedoman dalam menjalankan kehidupan.

Kebijaksanaan pemimpin adalah cerminan hati nurani yang diperoleh dari refleksi ajaranajaran agama yang terakumulasi dalam ruang pikiran dan secara seimbang terefleksi lewat indria-indria yang mencerminkan tingkah laku. Pengelolaan kebijaksanaan jiwa seorang pemimpin perlu adanya sebuah "manajemen hati nurani" yang secara eksternal mampu mengelola relasi dan interaksi di dalam sebuah komunitas agar tercipta keharmonisan. Pemimpin yang mampu mengelola kebijaksanaannya melalui manajemen hati nurani akan mampu berlaku adil kepada masyarakatnya sebagaimana halnya pohon cendana yang senantiasa menebarkan bau harum kepada siapa saja yang mendekatinya.

Surbakti (2012: Viii) juga menjelaskan bahwasanya pemimpin yang bijaksana seyogianya memiliki kecakapan hati nurani, agar mereka memiliki instrumen untuk mengendalikan tindakan. Kecakapan hati nurani akan membangkitkan loyalitas dan komitmen untuk "melayani" dan bukan untuk "di layani" dalam melaksanakan kepemimpinan mereka. Kecakapan hati nurani akan memampukan seorang pemimpin menghadapi berbagai tantangan, rintangan, dan intrik-intrik di dalam sebuah komunitas. Salah satu contoh tantangan bagi kebijaksanaan seorang pemimpin adalah dalam proses memilih secuil nilai-nilai kebaikan dalam lingkaran keburukan, sebagaimana yang diungkapkan dalam Kakawin Niti Sastra, III. 9 :

Warāmeta mawor lawan wiśa tang āmerta tikang alapen tekapnira. Ikāng kanaka len puriśya mapulang, kanaka juga kapeta kumbahen. Gunottama waropadeśa yadi tucca kahananira yogya yan prihen. Adhasstha wetuning wadhüttama surūpa

\section{halapenira sang mahājana.}

Terjemahan :

Jika madu tercampur dengan racun, kita harus dapat mengambil madunya. Dari campuran emas dan kotoran, harus diambil hanya emasnya lalu dicuci. Layak kita menuntut kepintaran dan pelajaran yang baik-baik. Biarpun kepada anak kecil. Perempuan berasal dari kalangan rendah, asal ia cantik dan kelakuannya baik patut diambil oleh orang besar (Tim, 1987: 24).

Maksud dari kutipan kakawin tersebut adalah, seorang pemimpin hendaknya mampu memilah apa yang berpotensi untuk menunjang kesejahteraan masyarakatnya dan mana yang membahayakan masyarakatnya. Untuk mengetahui hal tersebut, seorang pemimpin harus terjun langsung menemui masyarakat atau undang masyarakat mapun perwakilannya untuk hadir menemui sang pemimpin dalam rangka jajak pendapat (pabligbagan) tentang situasi dan kondisi sosial yang terjadi dalam masyarakat. Melalui proses tersebut tentunya akan ada sebuah fenomena silang pendapat yang terjadi. Di sanalah seorang pemimpin harus bijaksana dalam memilah dan menyimpulkan segala macam pendapat menjadi sebuah solusi untuk mengatasi segala macam permasalahan. hal tersebut diumpamakan sebagai seorang raja yang akan memilih seorang gadis sebagai permaisurinya. Sekalipun berasal dari golongan rendah namun baik budinya, tentunya layak untuk diperisterikan. Begitu juga halnya dalam proses musyawarah, sekalipun usulan tersebut berasal dari orang yang berkasta rendah dan miskin, namun jika usulanya mampu memajukan kesejahteraan bersama maka layaklah diambil sebagai sebuah kebijakan.

Dapatdisimpulkanbahwanilaikebijaksanaan dalam Kakawin Niti Sastra berorientasi pada pengetahuan suci yang harus dimiliki oleh seorang pemimpin dalam mengemban tanggung jawabnya didalam membina masyarakatnya. Pengetahuan suci ini mampu memberikan sebuah kesadaran bagi seorang pemimpin untuk membedakan mana perbuatan yang baik atau buruk sehingga nantinya mampu memilah hal-hal pokok mana yang harus dijalankan dalam konteks pengambilan keputusan 
ataupun dalam menghadapi masyarakatnya yang bersifat heterogen dalam kapasitasnya sebagai seorang pemimpin dan pengayom masyarakat.

\subsection{Kaprahitaning Praja (Welas Asih)}

Welas asih menurut Wiana (1996: 200) adalah rasa kasih seseorang (raja) yang mendorong kegiatan untuk menolong orang-orang yang sedang menderita, baik menderita kemiskinan material maupun kemiskinan rohani. Pada dasarnya setiap agama mengajarkan umatnya untuk senantiasa memupuk dan mengamalkan ajaran welas asih. Sifat welas asih menandakan bahwa manusia adalah cerminan makhluk Tuhan yang di satu sisi memiliki pikiran dan di sisi lain memiliki hati nurani untuk senantiasa peduli (respek) dengan penderitaan orang lain. kata kunci dari terwujudnya sifat ini adalah menghilangkan segala bentuk sifat dengki kepada orang lain dan menganggap orang lain itu sebagai saudara kita sendiri.

Dalam kitab Weda sendiri, sifat welas asih seorang pemimpin ditandai dengan sifat murah hati, suka menolong, dermawan yang disabdakan oleh Tuhan Yang Maha Esa untuk dipedomani oleh umat manusia. seorang pemimpin yang dermawan akan memperoleh kemuliaan. Bermacam-macam benda dapat atau pengetahuan dapat didermakan, mulai dari yang paling murah misalnya memberikan air putih bagi yang kehausan, memberikan makanan bagi yang kelaparan, memberikan pendidikan kepada mereka yang bodoh adalah langkahlangkah nyata untuk melatih diri, mempraktekkan kedermawanan. Kemurahan hati adalah wujud dari Dharma, yakni berupa pemberian atau Dana, sebagaimana yang diungkapkan dalam mantram Atharvaveda III. 24. 5 :

\section{Śata-hasta samā hara \\ Sahasrahasta sam kira}

Terjemahan :

Wahai umat manusia, perolehlah kekayaan dengan seratus tangan dan dermakanlah itu dalam kemurahan hati dengan seribu tanganmu (Titib, 1998: 319).
Maksud dari kutipan mantram tersebut adalah sebagai manusia yang baik, upayakanlah mencari kekayaan dengan cara yang benar. Begitupula dengan upaya untuk memperoleh kedudukan sebagai seorang pemimpin. Hendaknya dilakukan dengan jalan yang sesuai dengan kaidah-kaidah dan norma-norma yang telah ditentukan. Perlu disadari bahwasanya segala kesuksesan yang diperoleh bukanlah semata-mata berasal dari diri sendiri saja melainkan ada banyak orang-orang yang turut serta membantu baik dalam segi proses maupun dalam lingkup doa. Maka dari itu seorang pemimpin hendaknya memiliki sifat welas asih untuk mendermakan sebagian kekayaannya kepada rakyatnya yang mengalami kesusahan. Sebagaimana yang diungkapkan dalam kutipan Kakawin Niti Sastra IV. 6 :

Wwang dīnātithi yogya yan sungana dāna tekapira sang uttameng prajā

Mwang dewa-sthana tan winursita rubuh wangunen ika paharja sembahen.

Dina preta sangaskaran-ta pahayun lepasakena tekeng śmaśana ya.

Byaktā lābhaning aśwamedha-kretu lābhanira siniwi ring surālaya.

Terjemahan :

Orang terkemuka patut memberi sedekah kepada tamu yang miskin, membangun kembali candi yang sudah roboh dan tidak terpakai lagi, lalu mengiasinya supaya dapat dipergunakan lagi sebagai tempat bersembahyang. Ia patut mengadakan korban bagi jiwa-jiwa yang sengsara, supaya jiwa-jiwa itu terlepas dari kubur. Dengan jalan begitu ia berjasa seperti orang yang mengadakan kurban aswameda. Ia akan dimuliakan di Suralaya (Tim, $1987: 28$ ).

Orang terkemuka yang dimaksud dalam kutipan kakawin diatas adalah para pemimpin. Cerminan rasa welas asih seorang pemimpin secara horisontal terlihat tatkala memperlakukan masyarakatnya yang miskin bagaikan tamu yang patut dihormati dan dilayani dengan baik. Pemimpin harus menyadari bahwa adanya rakyat miskin tersebut membawa peranan yang sangat besar dalam proses pengukuhan dirinya sebagai seorang pemimpin. Secara vertikal, pemimpin 
harus mencurahkan rasa welas asihnya kepada Tuhan sebagai asas tertinggi yang meng-adakan dan me-niada-kan segala sesuatu yang ada di dunia ini. Berikanlah perhatian kepada tempat suci yang sudah mengalami kerusakan agar segera diperbaiki sehingga memberikan suasana yang kondusif bagi masyarakat dalam melakukan kegiatan keagamaan.

Kepedulian yang tidak kalah penting bagi seorang pemimpin adalah tidak hanya memperhatikan masyarakatnya ketika hidup saja, melainkan juga pada saat kematiannya. Jikalau ada masyarakat yang tidak mampu mengupacarai kerabatnya yang meninggal, maka sudah sepantasnya seorang pemimpin yang mengambil alih kewajiban tersebut sebagai bentuk tanggung jawab moralnya kepada rakyat. Jikalau hal tersebut mampu dilakukan, kemuliaan seorang pemimpin disamakan dengan seorang raja yang melakukan upacara aswameda. Svami Vivekananda menyatakan tiga hal yang patut didermakan adalah Vidyādāna (memberikan pengetahuan), Dharmadāna (memberikan pendidikan budhi pekerti yang luhur untuk merealisasikan ajaran agama), dan Arthadāna (memberikan materi yang dibutuhkan) (Titib, 1998: 318).

\subsection{Kawiryan (Keberanian)}

Keberanian dalam Kamus Lengkap Bahasa Indonesia, merupakan sifat tidak takut menghadapi bahaya atau kesulitan, tidak gentar, lawan takut (Nurhayati, 2012: 136) Keberanian adalah kemampuan untuk menghadapi ketakutan, derita, resiko, bahaya, ketidaktentuan, atau intimidasi. "keberanian fisik" adalah keberanian dalam menghadapi derita fisik, kesukaran, kematian atau ancaman kematian, sementara "keberanian moral" adalah kemampuan untuk bertindak secara benar walaupun banyak orang tidak setuju, walaupun dapat bersifat memalukan, walaupun bersifat skandal, atau tidak ada dukungan dari orang lain. keberanian terjadi ketika orang tidak terlalu pengecut dan tidak terlalu sembrono. Setidaknya itulah definisi yang diberikan Aristoteles terhadap keberanian dalam bukunya "Nicomachean Ethics" Sebagai kualitas yang diinginkan, keberanian memang banyak dipuji sebagai nilai yang utama dalam hidup ini, diberbagai ajaran agama dan filsafat, disetiap zaman, dan diberbagai belahan bumi (Mustari, 2014: 200).

Untuk mewujudkan sikap yang berani haruslah bisa melenyapkan rasa takut. Untuk melenyapkan rasa takut, maka dekatkan diri dengan Tuhan Yang Maha Esa, sebab beliau adalah sahabat terdekat bagi umat manusia. Perlindungan Tuhan Yang Maha Esa menyebabkan rasa keberanian itu muncul. Tuhan Yang Maha Esa akan senantiasa melindungi seseorang dari segala macam rintangan dan membimbing umatnya untuk senantiasa menuju jalan aman sesuai dengan ajaran Dharma. Hal ini dijelaskan dalam mantram Atharvaveda XIX.15.6 :

Abhayam mitrād Abhayam mitrād Abhayam jnatād abhayam puro yah Abhayam naktam abhayam divā nah Sarvā àśā mama mitram bhavantu

Terjemahan :

Semoga kami tidak takut pada kawan dan lawan. Lebih dari itu, semoga kami tidak takut pada yang dikenal dan tidak dikenal. Pada waktu yang sama, semoga kami tidak takut di malam hari dan siang hari. Semoga semua arah bersahabat kepada kami (Titib, 1998; 385).

Seorang pemimpin yang andal, lahir dari kekuatan keberanian terdalam dari dirinya, yang telah secara sempurna mampu menaklukkan semua rasa takut untuk selamanya. Sikap berani pemimpin merupakan senjata yang paling hebat dan paling sakti dibanding senjata yang lainnya. Pemimpin tanpa keberanian tidaklah pantas untuk disebut sebagai pemimpin. Keberanian itu haruslah sebagai sikap perjuangan yang jelas dan dapat dipertanggungjawabkan dengan segala nilai kebenaran.

Keberanian bukan berarti asal maju tanpa berhitung risiko, tapi keberanian itu adalah semua perilaku strategis yang telah terhitung secara akurat sebelum melangkah ketindakan lebih jauh. Keberanian itu tidak sama dengan nekat atau asal maju, yang tanpa memahami dan mengetahui segala hal secara sempurna, tapi keberanian itu 
sebuah sikap atau karakter yang didukung oleh data dan informasi yang benar. Bila keberanian di jiwa itu bermakna nekat atau asal berani, tanpa mempelajari semuanya secara sempurna, maka sesungguhnya sebagai seorang pemimpin telah buta untuk melihat makna keberanian secara benar dan tepat. Keberanian itu harus ada dasarnya, harus ada manfaatnya, harus ada tujuannya, dan harus ada rencana matangnya. Keberanian seorang pemimpin merupakan salah satu nilai kualitas tertinggi dari kepemimpinan yang cerdas dan menjadi panutan sebagaimana yang diungkapkan dalam kutipan Kakawin Niti Sastra XV. 11:

Pathyā tigolahên ikā mapatih wiçesa lêngkêp wruhing guna samāpta lawan kaçūrandhamārthakāma kawênang ya kaciçcayeng twas yan nirguneku tilarên têkap narendra.

\section{Terjemahan :}

Tiga macam yang pantas menjadi tabiat raja besar, yaitu: ia harus tahu mana-mana yang berguna, ia harus gagah berani dan mempunyai keyakinan dapat mencapai suatu yang halal, bergunan dan layak. Apa yang tiada berguna harus ditinggalkan raja (Tim, 1987: 60).

Salah satu keberanian yang dituntut dari seorang pemimpin adalah keberanian untuk mengambilresiko. Keberanianiniakanmenentukan nasib hidup orang banyak. Berani mengambil resiko adalah kewajiban bagi seorang pemimpin. Dengan keberanian mengambil resiko seorang pemimpin dilatih untuk bersikap konsekuen dan fair. Perlu belajar dan bekerja sungguh-sungguh, karena pilihan tidak bisa diambil seenaknya. Resiko memang selalu menanti di tengah jalan, tapi itu semua haruslah dapat diperhitungkan. Itulah yang biasanya disebut manajemen resiko (risk management) (Mustari, 2014: 201).

Dengan berani mengambil resiko sebenarnya seorang pemimpin telah menunjukkan integritasnya meskipun kadangkala resiko yang diambilbersifatkurangmenguntungkan. Pemimpin dengan integritas sudah memiliki keberanian, untuk menghadapi dan mengelola risiko secara baik dan profesional. Keberanian dan integritas adalah dua sifat yang sangat penting bagi seorang pemimpin. Sehebat dan sebaik apapun seorang pemimpin, bila dia tidak memiliki keberanian, dia akan menjadi bagian dari masalah, dan tidak akan pernah bergerak untuk menemukan solusi kemenangan. Pemimpin haruslah berani, tegas, jelas, serta cerdas mengelola dan menghadapi realitas melalui integritas yang hebat. Keberanian haruslah menjadi bagian dari gaya hidup dan pola kerja seorang pemimpin. Pemimpin yang berani tidak akan membiarkan kesulitan apapun menahan atau menghalangi niat, untuk bertindak dan melakukan sesuai misi dan keyakinan. Seorang pemimpin akan memperkuat kualitas integritasnya, sehingga semua yang dilakukan sudah terkoordinasi di dalam bingkai moral dan etika, yang dapat dipertanggung jawabkan secara profesional.

Dari berbagai jenis kepribadian, keberanian ini termasuk kategori kepribadian internal, yang didefinisikan sebagai kepribadian yang menggambarkan keyakinan seseorang bahwa segala sesuatu yang terjadi pada diri adalah ditentukan oleh diri sendiri (internal locus of control). Sebaliknya, ada kepribadian seseorang yang memiliki keyakinan bahwa apa yang terjadi pada diri sangat ditentukan oleh faktor luar (External locus of control). Keberanian (Risk Taking) merupakan suatu kepribadian yang menunjukkan sifat-sifat berani mengambil suatu tindakan yang cepat dan mengambil keputusan yang cepat dengan informasi yang minimal atau keberanian mengambil resiko (Badeni, 2013: 2325).

Dalam menghadapi musuh secara fisik, seorang pemimpin hendaknya tidak menunjukkan wajah ketakutan sekalipun tahu bahwa lawan nyatanya lebih tangguh agar pasukan yang dimiliki tetap bertahan. Hadapilah musuh dengan tenang bukan dengan hinaan, nyalakanlah api keberanian dalam diri sebagai konsekuensi pertaruhan harga diri meskipun harus rela mati. Hal ini tentunya sebagai bentuk kamuflase untuk mengelabui lawan demi mempertahankan semangat juang para pasukan, hal ini dijelaskan dalam kutipan 
Kakawin Niti Sastra, II.4 :

Hawya Kaciryan ing para yadin hana kinakutan

Dhairya juga prihên galakaning balagana Malaga

Tan hawamāna rin ripu musuhta mawuwuh agalak

Bahni manahnirānggêsêngi tan hana pangucapira.

Terjemahan :

Jika engkau merasa ketakutan, janganlah diperlihatkan kepada orang lain. Ikhtiarkan saja, supaya tentaramu bertahan dan menyerang dengan gagah berani. Jangan menghina musuh, karena sikapmu itu akan menambah amarahnya. Nyala-nyalakan hatimu, akibatnya akan dapat menghanguskan. Dengan tidak mengucapkan apapun juga (Tim, 1987: 17).

Menyalakan api dalam diri adalah proses untuk membangkitkan kembali semangat juang dan keberanian yang semakin redup. Ketakutan bisa jadi menimbulkan sebuah keraguan untuk bertindak. Tak perlu banyak bicara dalam membinasakan lawan. Cukup dengan sebuah keyakinan dan keberanian yang bijak akan mampu menyatukan segala bentuk kekuatan untuk memperkokoh pondasi perlawanan yang tiada henti digempur oleh kekuatan musuh. Keberanian seringkali memaksa seorang pemimpin untuk bertindak menyakiti lawan. Meskipun terkesan kejam, namun kebenaran (Dharma) hendaknya selalu ditegakkan demi terwujudnya kehidupan yang damai.

\subsection{Wibhawa (Kewibawaan)}

Perbuatan mulia pada hakekatnya merupakan salah satu faktor mengapa seorang pemimpin dikatakan berwibawa dan dikagumi rakyatnya. Perbuatan mulia mengantarkan seorang pemimpin pada keluhuran budi. Pemimpin yang mengembangkan keluhuran budi ibarat menebarkan benih yang baik di tanah yang subur, niscaya pada saatnya, benih itu akan menghasilkan buah yang bermanfaat (Titib, 1998: 327).

Dalam konteks pikiran, kewibawaan seorang pemimpin akan muncul apabila ia memiliki kepintaran dalam berbagai bidang. Kepintaran akan diperoleh seorang pemimpin apabila mau belajar dengan baik. Tahap untuk mencapai kepintaran dapat diperoleh pada masamasa brahmacari. Sebagai contoh para Pandawa yang tiada lain merupakan putra Pandu dalam epos Mahabharata sangat tekun dalam menempuh pendidikan pada gurunya Drona (Dronācarya). Arjuna begitu berwibawa karena pandai memanah (Arjuna dalam epos Mahabharata adalah simbol kecerdasan, intelektualitas, penguasaan ilmu dan teknologi dari seorang pemimpin) (Samba, 2013: vi). Begitu juga dengan saudaranya yang lain sangat berwibawa dengan keahliannya masing-masing. Semua itu karena kepintaran. Jika pemimpin tidak pintar dalam hal pemikiran maka wajahnya sendiri secara simbolis akan nampak kusam tiada bercahaya sebagaimana yang diungkapkan dalam kutipan Kakawin Niti Sastra II.7 :

Nemani sang mamukti dumadak tika tan ana guna

yowana rūpawān kula wiçāla tika pada hana

denika tanpa sastrā tan ateja wadana makucên

lwir sêkaring çami murub abāng tan ana wanginika.

Terjemahan :

Sangat disayangkan, jika orang kaya tiada mempunyai kepintaran.

Biarpun muda, bagus, turunan bangsawan, dan kesehatannya baik, jika tidak berkepandaian, tentu mukanya kusam, tiada bercahaya, seperti bunga kapuk hutan, yang merah merang tetapi tiada semerbak baunya (Tim, 1987: 18).

Seorang pemimpin tidak akan bisa disebut pemimpin apabila tidak ada rakyat yang mengakuinya. Begitu juga halnya dengan seorang pemimpin jika ingin berwibawa di mata rakyatnya haruslah bisa memposisikan diri secara positif serta menjalin hubungan yang baik dengan masyarakatnya, hubungan tersebut secara implisit diumpamakan sebagai singa dan hutan yang saling menjaga sebagaimana yang diungkapkan dalam 
kutipan Kakawin Niti Sastra I.10 :

Singhā rakssakaning halas ikangrakseng harī nityaça.

singhā mwang wana tan patūt pada wirodhāngdoh tikang keçari.

rug brāsta ng wana deningkang jana tinor wrêksanya çirnapadang.

singhānghot ri jurangnikang têgal ayūn sāmpun dinon durbala.

Terjemahan :

Singa adalah penjaga hutan, akan tetapi juga selalu dijaga oleh hutan. Jika singa dengan hutan berselisih, mereka marah, lalu singa itu meninggalkan hutan. Hutannya dirusak binasakan orang, pohon-pohonnya ditebangi sampai menjadi terang. Singa yang lari bersembunyi di dalam curah, ditengah-tengah lading, diserbu orang dan dibinasakan (Tim, 1987: 14).

Perumpamaan hubungan singa dengan hutan mengingatkan kembali tentang hakikat hubungan bhuana alit (alam kecil/makhluk hidup) dengan bhuana agung (alam besar/jagat raya). Jikalau manusia selaku aspek bhuana alit merusak alam semesta/bhuana agung maka alam semesta juga akan menghancurkan eksistensi manusia melalui bencana alam. Sebagai contoh, penebangan liar yang dilakukan manusia akan berimbas pada terjadinya tanah longsor yang menyebabkan manusia menjadi korbannya. Mengganggu eksistensi alam berarti merusak badan wadah Hyang Widhi. Karena Hyang Widhi yang menciptakan alam sebagai badan wadah untuk menjadikan badan-Nya itu sebagai media kehidupan manusia makhluk hidup lainnya (Tim, 2013: 268).

Singa sebagai simbol kewibawaan pemimpin hendaknya tidak menimbulkan sebuah aura ketakutan diwilayah tempatnya memimpin, apalagi sampai merusak tatanan kehidupan sosial dan ekologi wilayahnya, baik melalui kebijakan maupun tindakan yang cenderung bertolak belakang dengan konstitusi dan kedaulatan sebuah negara. Seyogyanya, pemimpin harus mengimplementasikan nilai-nilai kewibawaanya dengan cara menjaga hubungan yang harmonis dengan masyarakat maupun wilayah pemerintahannya agar sama-sama saling mendukung eksistensi masing-masing.

\section{PENUTUP}

Konsep Kepemimpinan Catur Kotamaning Nrepati dalam Kakawin Niti Sastra diawali dengan struktur kepemimpinan yang terdiri dari Prabhu (raja), Purohita (pendeta istana), Amatya (menteri), Nāradhipati (pemimpin tentara), Sena (tentara) dan Sanggya (rakyat/ masyarakat). Konsep kepemimpinan tersebut dapat diuraikan kedalam empat bagian yaitu nilai kebijaksanaan (jnana wisesa suddha) yang intinya seorang pemimpin harus memiliki pengetahuan suci didalam mengemban tanggung jawabnya untuk membina masyarakat. Pengetahuan suci ini mampu memberikan sebuah kesadaran bagi seorang pemimpin untuk membedakan mana perbuatan yang baik atau buruk. Nilai welas asih (kaprahitraning praja) yang intinya seorang pemimpin harus memiliki rasa kepedulian kepada rakyatataubawahannya danmencurahkannyalewat bantuan berupa ilmu pengetahuan, pendidikan moral maupun harta benda. Nilai keberanian (kawiryan) yang intinya seorang pemimpin harus berani mengambil resiko dalam mencapai tujuan bersama dengan penuh pertimbangan dan rasa tanggung jawab. Nilai kewibawaan (wibhawa) yang intinya seorang pemimpin akan berwibawa apabila mampu memposisikan diri dan mengambil hati masyarakatnya dengan jalan berkata dan bertingkah laku yang baik.

\section{DAFTAR PUSTAKA}

Atmadja, Nengah Bawa. 2014. Saraswati dan Ganesha Sebagai Simbol Paradigma Interpretativisme Dan Positivisme, Visi Integral Mewujudkan Iptek Dari Pembawa Musibah Menjadi Berkah Bagi Umat Manusia. Denpasar: Pustaka Larasan; IBIIK BCCC Undiksha Singaraja; Universitas Hindu Indonesia.

Awanita, dkk. 1995. Sila dan Etika Hindu. Jakarta; Direktorat Jenderal Bimbingan Masyarakat 
Hindu dan Budha.

Badeni. 2013. Kepemimpinan dan Perilaku Organisasi. Bandung: Alfabeta.

Koentjaraningrat. 2009. Pengantar Ilmu Antropologi. Jakarta: Rineka Cipta.

Mustari, Mohamad. 2014. Nilai Karakter, Refleksi Untuk Pendidikan. Jakarta: PT Raja Grafindo Persada.

Nurhayati, Tri Kurnia. 2012. Kamus Lengkap Bahasa Indonesia. Jakarta: Eska Media.

Pudja, G, dan Sudharta, Tjokkorda Rai. 2002. Manawadharmasastra. Jakarta: CV. Felita Nursatama Lestari.

Samba, I Gede. 2013. Pencarian Ke Dalam Diri, Merajut Ulang Budaya Luhur Bangsa. Bandung: Yayasan Dajan Rurung.

Subagiasta, I Ketut. 2010. Kepemimpinan (leadhership) Dalam Agama Hindu. Surabaya: Paramita.

Surbakti. 2012. Manajeman Kepemimpinan Hati Nurani. Jakarta: PT Gramedia.

Suyana, I Gede. 2011. Kepemimpinan Bendesa Adat Di Desa Penyaringan Kecamatan Mendoyo Kabupaten Jembrana (Perspektif Nitisastra). (Tidak Diterbitkan). Denpasar: Unhi

Thoha, Miftah. 2012. Kepemimpinan Dalam Manajemen. Jakarta: PT Raja Grafindo Persada.

Tim. 1987. Niti Sastra Dalam Bentuk kakawin. Singaraja: Proyek Penerangan Bimbingan dan Da'Wah/Khutbah Agama Hindu dan Buddha.

Tim. 2013. Swastikarana, Pedoman Ajaran Hindu Dharma. Jakarta: PHDI Pusat.

Titib, I Made. 1998. Weda Sabda suci Pedoman Praktis Kehidupan. Surabaya: Paramita.

Wiana, I Ketut. 1996. Nitisastra. Jakarta: Dirjen Bimas Hindu dan Buddha.

Zoetmulder, P.J. 1985. Kalangwan Sastra Jawa Kuno Selayang Pandang. Jakarta: Djambatan.
Zoetmulder, P.J. 1997. Kamus Jawa KunaIndonesia. Jakarta: PT Gramedia Pustaka Utama. 